\title{
Demokrasi Sosial dalam Pemikiran Paul Feyerabend
}

\author{
Dodo Widarda
}

(Fak. Ushuluddin UIN Sunan Gunung Djati, Bandung, Indonesia; dodoabidarda@gmail.com)

\begin{abstract}
This article reevaluates Feyerabend's thought in formatting social order based on his concept of Anything Goes. The discussion is a new challenge for social studies in the new circumstances and time. By taking Feyerabend's books this study describes and analyzes the format of Feyerabend's thought, what are being rejected by him, and what is being proposed by bim in order to develop democracy in the community. By his effort, it is clear that Feyerabend places democracy as his fundamental reference for his idea of intellectual movement. Finally, this article contextualizes Feyerabend's thought with what being happened in our time.
\end{abstract}

Key words: Feyerabend, speculative thought, social democracy.

\begin{abstract}
Abstrak
Artikel ini mengkaji kembali pemikiran Paul Feyerabend dalam pembentukan tatanan sosial yang berdasarkan idenya bahwa Anything Goes. Diskusi ini merupakan tantangan baru bagi kajian kemasyarakatan dan lingkungan dalam zaman baru manusia. Dengan mengambil teks-teks dari buku-buku Feyerabend, kajian ini mendeskripsikan apa yang menjadi formasi pemikiran Feyerabend, apa yang ia tolak, dan apa yang ia ajukan untuk mengembangkan masyarakat yang demokratis. Dengan usahanya itu, sangat jelas bahwa Feyerabend menempatkan demokrasi sebagai rujukan utama gerakan pemikirannya. Akhirnya, kajian ini pun mengkontekstualisasi pemikiran Feyerabend pada kondisi kekinian.
\end{abstract}

Kata Kunci: Feyerabend; pemikiran spekulatif; demokrasi sosial.

A. Pendahuluan

Problematika sosial selalu menantang manusia untuk merumuskan kembali apa yang terjadi dan apa yang seharusnya terjadi. Dari sini muncul ide-ide tentang bagaimana sebaiknya bermasyarakat dengan argumen-argumen filosofis. Argumenargumen itu membentuk teori-teori. Dan teori-teori itu berkompetisi dan saling 


\section{ARTIKEL}

melakukan persuasi. Demikian sehingga teori-teori itu memunculkan keraguankeraguan epistemologis (Rahman, 2018: 160-1). Teori Feyerabend tentang Anarkisme Epistemologis sangat terkenal, termasuk dalam kajian Sosiologi. Teori ini berusaha untuk memecahkan kemandegan dari teori klasik yang telah sampai pada situasi 'krisis' serta memerlukan sebuah perumusan ulang menyangkut visi dan cara-cara manusia berada di dunia.

Feyerabend (1924-1994) asalnya adalah pendukung teori klasik dan seorang penganut rasionalisme, kemudian pemikirannya berubah. Ada beberapa faktor yang tampaknya memberi pengaruh terhadap Feyerabend untuk mengubah haluan pemikirannya. Hal paling utama berkaitan dengan penemuan fisika quantum yang telah mengkandaskan premis-premis dasar paradigma Cartesian-Newtonian. Padahal, ilmu fisika dianggap memiliki derajat kepastian eksak yang di atasnya nilai-nilai positivisme ditegakkan. Memang, penemuan fisika quantum yang dianggap memberikan sebuah warna baru bagi perkembangan ilmu pengetahuan sehingga mendapatkan sambutan luar biasa dari para fisikawan serta filosof. Dalam mengubah pemikirannya, Feyerabend mendapat pengaruh yang kuat dari para pemikir seperti Ludwig Wittgenstein, David Bohm, Niels Bohr, Anscombe, Thomas Kuhn, serta terutama Imre Lakatos, yang semuanya memberi warna pada perkembangan pemikirannya.

Prinsip Anything Goes (Apa Saja Boleh) adalah sebuah tesis perlawanan terhadap cara pandang ilmiah yang hegemonik dengan memberi dasar-dasar dekonstruksi teks untuk menolak klaim kebenaran yang universal. Seperti juga para pemikir lain yang telah memberikan fundamen-fundamen kritis, baik pada level teoretis maupun praktis, maka upaya-upaya yang telah diperjuangkan Feyerabend, 
membawa cita-cita perubahan baik pada level ilmiah maupun dalam perjuangan memperbaharui pandangan kemanusiaan dengan wawasan yang lebih baru, dalam pengertian yang seluas-luasnya.

Maka, tendensi pemikiran postmodernismenya, jika kemudian diperjuangkan secara konsisten, akan memiliki implikasi mendasar, baik pada level filosofis maupun praktis. Baik untuk demokrasi ilmiah maupun demokrasi sosial. Selain itu, gagasangagasannya juga mengarahkan posisi yang tepat terhadap para ilmuwan, untuk dapat berjuang di tengah-tengah masyarakatnya.

\section{B. Metode}

Metode yang digunakan dalam penelitian ini adalah Metode Penelitian Filsafat yang telah diangkat menjadi suatu ilmu yang berdiri sendiri. Metode ini dapat diartikan "Suatu cara atau jalan yang ditempuh dalam suatu proses tindakan, rangkaian langkah-langkah yang dilakukan secara terencana, sistematis untuk memperoleh pemecahan permasalahan atau jawaban pertanyaan tentang kefilsafatan." Aspek metodologi penelitian filsafat yang dipakai adalah interpretasi. Interpretasi menafsirkan, membuat tafsiran, tetapi yang tidak bersifat subyektif (menurut selera orang yang menafsirkan), melainkan harus bertumpu pada evidensi obyektif untuk mencapai kebenaran yang obyektif. Dengan interpretasi diharapkan manusia dapat memperoleh pengertian, pemahaman atau verstehen. Pada dasarnya interpretasi berarti tercapainya pemahaman yang benar mengenai ekspresi manusia yang dipelajari (Sudarto, 1996: 42). Interpretasi itu sendiri muncul dari upaya penelusuran teks dengan analisis wacana, yaitu penyelidikan makna teks berdasarkan penafsiran linguistik (Johnstone dalam Rahim, et.al., 2018). 


\section{ARTIKEL}

E-ISSN: $2615-5028$

Filsafat adalah ilmu yang menyelidiki segala sesuatu secara mendalam terkait dengan masalah Ketuhanan, alam semesta serta manusia (Pandarakalam, 2019). Di sini filsafat memerlukan ilmu lain sebagai sumber pengalaman yang otentik. Kalau filsafat berusaha mengembangkan hubungan yang mendasar antara Tuhan, alam dan manusia, maka, "ilmu lain" yang penulis pakai dalam tulisan ini, adalah teori struktural genetik Lucien Goldmann (2013) yang berusaha merumuskan perspektif yang komprehensif, termasuk terkait pola hubungan manusia beserta struktur sosial yang melingkunginya, dan juga dengan Tuhan. Teori ini diambil untuk mengatasi pendekatan struktural yang sangat rigid untuk mengungkapkan kompleksitas problematika kehidupan manusia.

\section{Hasil dan Pembahasan}

\section{Paul Feyerabend dan Against Method}

Paul Feyerabend lahir di Wina pada tahun 1924, anak dari orang tua sipil serta tukang jahit, namun termasuk dalam keluarga kelas menengah Wina. Feyerabend lahir ke dunia pada saat-saat yang sulit sebagai akibat dari Perang Dunia I di mana terjadi kelaparan, kekacauan, serta inflasi tak terkendali (Falckenberg, 2019).

Paul Feyerabend adalah seorang filosof sains yang memiliki tempat tersendiri di tengah-tengah diskursus sains kontemporer. Pandangan-pandangannya dapat ditempatkan dalam konteks arus perubahan mendasar paradigma ilmu pengetahuan pada abad ke-20 dengan gaya penyampaian yang sangat provokatif, dan bahkan revolusioner. Dia berusaha mendobrak ilmu pengetahuan yang secara sistemik, telah mengalami kejumudan serta menjadi begitu tertutup terhadap realitas di luar dirinya. 
Maka, Feyerabend (1924-1994), yang telah belajar ilmu pengetahuan di Universitas Wina dan kemudian melanjutkan program filsafat untuk tesis doktoralnya, telah menciptakan nama buat dirinya sendiri sebagai bagian dari pendobrak filsafat sains, bahkan kemudian menjadi kritikus dari 'rasionalisme kritis' Popper dan menjadi sosok paling terkenal filosof ilmu pengetahuan pada abad ke-20 (Falckenberg, 2019).

Pertemuan dengan Imre Lakatos memberikan sebuah pengaruh mendasar terhadap Paul Feyerabend dan itu terjadi di jantung kota Inggris, London. Di London, saat dia memberikan perkuliahan di University College serta London School of Economics pada awal 1970-an, dia bertemu dengan seseorang yang kemudian memberikan pengaruh besar untuk menerbitkan karya-karyanya. Keduanya menjadi sahabat akrab yang terus menjalin hubungan satu sama lain secara tetap hingga peristiwa kematian Lakatos pada tahun 1974 (Ferry, 2019).

Pada awal 1970-an Feyerabend telah menjelaskan secara terperinci perspektif dia sendiri tentang metode ilmiah. Pada tahun 1970, dia telah mempublikasikan sebuah artikel panjang berjudul 'Against Method' yang di dalamnya dia menyerang sejumlah catatan penting dari metodologi ilmiah. Di dalam surat menyurat mereka, sesudahnya, dia dan Lakatos berencana mengembangkan sebuah volume debat serta diberi judul For and Against Method yang di dalamnya Lakatos menempatkan diri sebagai seorang rasionalis yang mempergunakan perangkat-perangkat kaidah metode ilmiah yang membuat seluruh ilmu pengetahuan 'mapan' dan Feyerabend akan melawannya. Lakatos, secara tidak diharapkan, wafat pada bulan Februari 1974, yang rupa-rupanya telah membuat Feyerabend shock secara mendalam, karena maksud dari bagian yang mesti diisi kaum rasionalis dari karya mereka bersama, belum lengkap (Ferry, 2019). 
Against Method yang terbit dalam bentuk buku lengkap pada tahun 1975 oleh penerbit New Left Books, London didedikasikan oleh Feyerabend untuk sahabat yang telah menabur benih-benih anarkisme di dalam pemikirannya. Sebuah deskripsi yang lebih akurat adalah yang ia berikan dalam biografi seperti dalam tulisan berikut: "AM is not a book, it is a collage. It contains descriptions, analyses, that I had published, in almost some world, ten, fifteen, even twenty years earlier... I arranged them in a suitable order, added transitions, replaced moderate passages with more outrageous ones, and called the result 'anarchism.' I loved to shock people." (Preston, 2002: 20).

Buku ini berisi tema-tema yang dijelaskan secara luas yang dilengkapi sebuah studi kasus dari perpindahan astronomi geosentris ke heliosentris. Feyerabend menekankan bahwa teori-teori ilmiah tertua, seperti teori gerak Aristoteles, memiliki landasan empiris serta dukungan argumentasi yang kuat. Sedangkan bagi Feyerabend, pahlawan revolusi ilmiah seperti Galileo tidak secermat sebagaimana yang digambarkan. Dia menggambarkan Galileo membuat retorika, propaganda dan beragam trik epistemologi untuk mendukung posisi teori heliosentris. Feyerabend juga mencari lebih jauh untuk menurunkan argumen-argumen empiris yang penting dengan mengusulkan kriteria estetis, perilaku-perilaku personal serta faktor-faktor sosial, memiliki peran yang jauh lebih menentukan di dalam sejarah ilmu pengetahuan dari historiografi kaum empiris serta rasionalis yang dapat ditunjukkan (Martin, 2019).

Against Method menggambarkan secara eksplisit konklusi 'Anarkisme Epistemologis' yang Feyerabend anggap akan mendorong kemajuan sains atau pertumbuhan ilmu pengetahuan. Dan satu-satunya prinsip yang tidak akan menghambat kemajuan itu, bagi Feyerabend adalah sebuah anjuran: Apa Saja Boleh 


\section{ARTIKEL}

E-ISSN: $2615-5028$

(Anything Goes). Prinsip itu yang dia pertahankan secara konsisten sampai kematiannya di Zurich, 11 Februari 1994 (Martin, 2019).

\section{Demokrasi Sosial}

Anarkisme Epistemologis dengan salah satu prinsip penting Anything Goes yang berpasangan dengan prinsip proliferation itu tidak hanya didedikasikan Feyerabend bagi kepentingan dunia ilmiah semata, tetapi juga bagi pergulatan di wilayah sosial yang lebih praktis. Bagi Feyerabend, Anarkisme Epistemologis tidak hanya penting bagi pengembangan metodologi, ini juga merupakan sebuah pandangan kemanusiaan seperti terungkap dalam tulisannya: "Pluralism of theories and metaphysical views is not only important for methodology, it is also an essential part of a bumanitarian outlook" (Feyerabend, 1982: 53). John Preston (2002: 21) menulis bahwa filsafat politik Feyerabend adalah campuran antara liberalisme dan gerakan demokrasi sosial.

Relevansi gerakan Anti Metode dari Feyerabend demikian terasa untuk menjernihkan pandangan kemanusiaan yang telah tereduksi oleh cara pandang dominan yang menindas. Ilmu pengetahuan telah melakukan kudeta terhadap peran yang dimainkan oleh kalangan agamawan. Bahkan dia telah menjadi agama itu sendiri. Dengan kondisi tersebut, seorang filsuf besar Perancis abad kedua puluh, Roger Geraudy menyampaikan pandangan kritisnya. Menurut Geraudy (1985: 100), sejarah sains dan teknik sebagaimana yang dikonsepsikan orang di negara-negara Barat didasarkan atas suatu postulat yang implisit: orang harus mengukur kemajuan sains dan teknik hanya dengan satu ukuran, yaitu apakah sains dan teknik itu dapat menjamin kekuasaan yang maksimum atas alam dan manusia. Sikap yang semacam 


\section{ARTIKEL}

E-ISSN: $2615-5028$

itu merupakan suatu definisi kuantitatif yang berarti kemauan untuk memperoleh kekuasaan dan mendominasi (walaupun kekuasaan itu jelas-jelas akan menyebabkan kehancuran alam dan manusia), begitu juga sains dan teknik yang membantunya, telah menjadi tujuan tertinggi, nilai yang satu-satunya, agama "kemajuan" (progress) dan "pertumbuhan" (growth).

Setelah sukses Abad Renaisans serta Abad Pencerahan membawa gelombang agama perkembangan dan kemajuan yang menjadikan manusia sebagai tuan dan pemilik alam, maka dunia kini memerlukan perumusan filosofis pasca dominasi paradigma Cartesian-Newtonian dalam menghayati hubungan segi tiga: alam, manusia dan Tuhan. Manusia, mesti dapat mengintegrasikan kembali hubungan ketiganya sebagai sebuah tujuan hidup, untuk mencapai tahapan perkembangan dirinya secara lebih utuh. Bagi Geraudy (1985: 100), manusia yang seutuhnya berarti manusia dalam segala dimensinya, termasuk di dalamnya hubungan estetik (keindahan) kita dengan alam sebagai partisipasi yang berbahagia kepada kehidupan alam tersebut, dan bukan sekedar anggapan bahwa alam itu hanya reservoir bahan baku dan tempat buangan yang tidak diperlukan, termasuk juga hubungan dengan lain-lain orang, tetapi bukan jenis hubungan persaingan, pertempuran atau dominasi sebagai yang dikatakan filsuf Inggris, Thomas Hobbes (1558-1679): "Homo homini lupus”, manusia yang satu adalah segala bagi manusia lainnya.

Integrasi antara manusia dengan manusia serta manusia dengan alam serta manusia dengan Tuhan adalah prasyarat untuk dapat menyelamatkan masa depan dari kehidupan serta kemanusiaan. Terkait hubungan manusia dengan Tuhan, arah perkembangan sains dan teknologinya, telah melenceng dari perumusan para pemikir awalnya sendiri. Ilmuwan-ilmuwan besar seperti Descartes, Newton, Francis Bacon, 
Galileo, Copernicus serta Keppler, ketika awal-awal kebangkitan ilmu pengetahuan modern, masih menyisakan ruang bagi agama di dalam perbincangan ilmu pengetahuan modern. Ada di antara mereka yang bahkan mencita-citakan terintegrasikannya penjelasan-penjelasan ilmiah dengan teks-teks kitab suci, pada suatu ketika dengan tidak menafikan antara yang satu dengan yang lainnya, pada suatu ketika. Akan tetapi ilmuwan-ilmuwan sekelas Laplace, D'Alembert, Thomas Hobbes, beserta para pendukung fanatiknya yang datang kemudian, memberikan penjelasan atas gejala alam sepenuhnya naturalis serta determinis. Pandangan inilah yang diterapkan secara radikal oleh gerakan positivisme Comte dan para pendukung gerakan Positivisme Logis seperti Ayer, Carnap, dan lain-lain.

Feyerabend bukan hanya mengkritik kecenderungan 'pemberhalaan' sains dalam masyarakat Amerika, tetapi dia mengkritik masyarakat Barat secara lebih menyeluruh. Feyerabend telah melihat keinginan dia sendiri untuk meruntuhkan argumen-argumen terhadap posisi hak-hak istimewa ilmu pengetahuan di dalam kebudayaan, dan banyak dari karya terakhir dia berupa kritik pada posisi pengetahuan di dalam masyarakat Barat. Sebab tidak ada metode ilmiah, kita tidak dapat membenarkan sains sebagai cara paling baik untuk mendapatkan pengetahuan. Dan hasil dari sains tidak membuktikan keunggulannya sendiri, karena hasil-hasil tersebut seringkali bergantung atas kehadiran elemen-elemen non-ilmiah (Feyerabend, 1978: 102). Dengan penuh semangat, Feyerabend menyampaikan sebuah anjuran: "Science is much closer to myth than a scientific philosophy is prepared to admit. It is one of the many form of thought that have been developed by man and not necessarily the best. It is conspicuous, noisy, and impudent, but it is inherently only for have already decided in favour of a certain ideology, or who 


\section{ARTIKEL}

E-ISSN: $2615-5028$

have accepted it without ever having examined its advantages and its limits." (Feyerabend, 1982: 295).

Agar sains terhindar menjadi alat penindasan bagi kekuasaan dominan makan Feyerabend menganjurkan pemisahan sains dari negara, menambahi pemisahan agama dari negara lewat gagasan sekuler seperti yang galib terjadi di negara-negara Barat. Banyak di antara para ilmuwan yang dengan objektif menilai berbagai aspek manipulatif yang terjadi di negara-negara Barat, yang berbarengan dengan perkembangan ilmu pengetahuan serta teknologi yang sudah mencapai tarap yang demikian maju. Dari titik inilah gagasan Feyerabend untuk memisahkan sains dengan negara di negara-negara Barat sangat penting untuk dibicarakan.

Problema pokok dunia sekarang dari problem kelaparan sampai problem persenjataan "yang merupakan dua wajah dari problem yang sama", kehilangan arti dan tujuan hidup di Barat, sebab dari semua itu adalah cara Barat mengadakan perkembangan yang berarti memproduksi lebih banyak, lebih lekas, apa saja, yang berfaedah, yang tidak berfaedah, yang mudarat bahkan mematikan seperti senjata nuklir dan memaksakan kepada semua orang untuk mengkonsumsikan, dengan cara lain, pemasaran, tetapi juga dengan cara yang kotor yang menimbulkan perbedaan yang besar dalam masyarakat (Geraudy, 1985: 236).

Secara cermat Geraudy menggambarkan perkembangan cara Barat mengeksploitasi kesengsaraan dan keinginan orang-orang yang lapar di dunia untuk memberikan ilusi kepada mereka. Adalah mungkin, bahkan wajib untuk mengikuti jalan perkembangan Barat ini agar dapat keluar dari kesengsaraan mereka dan dapat melihat terlaksananya keinginan-keinginan mereka (Geraudy, 1985: 235). Negaranegara Barat yang maju dari sisi perkembangan ilmu pengetahuan dan teknologi, 


\section{ARTIKEL}

cenderung menjadi kekuatan hegemonik serta dominan atas negara-negara dunia ketiga.

Kebangkitan ilmu pengetahuan modern, tulis Feyerabend berbarengan dengan penindasan atas suku-suku non-Barat, oleh penyerbu-penyerbu Barat. Sukusuku non-Barat, tidak hanya ditekan secara fisik, tetapi mereka juga kehilangan kebebasan intelektual. Sebagian terbesar dari anggota-anggota inteligen mereka mendapatkan sebuah bonus ekstra: mereka diantarkan ke dalam misteri-misteri rasionalisme Barat dan puncaknya -ilmu pengetahuan yang telah mereka hasilkan. Di dalam kasus-kasus terbesar tradisi menghilang tanpa menemukan sebuah argumen, seseorang secara mudah menjadi seorang budak baik secara tubuh maupun pikiran. Hari ini, perkembangan ini mulai berbalik secara bertahap.

Kebebasan diperoleh kembali, tradisi-tradisi lama ditemukan kembali, antara minoritas di negara-negara Barat dan antara populasi-populasi besar di benua-benua non-Barat. Tetapi, bagi Feyerabend, sains masih memegang kekuasaan tertinggi. Supremasi kekuasaan sains terjadi, sebab para pelaksananya tidak dapat memahami serta tidak mau menenggang perbedaan-perbedaan ideologi, sebab mereka memiliki kekuatan (power) untuk memuaskan harapan-harapan mereka. Selain itu, mereka juga mempergunakan kekuatan tersebut sebatas bagaimana leluhur-leluhur mereka telah melakukan untuk kekuatan dengan mengatasnamakan kristianitas atas orang-orang. Jadi, ketika seorang Amerika sekarang dapat memilih agama yang dia sukai, dia masih tidak mengizinkan tuntutan anak-anaknya belajar hal-hal magis daripada ilmu pengetahuan di sekolah. (Feyerabend, 1982: 299). Dari titik tolak pemikirannya yang sangat substantif, Feyerabend menilai bahwa telah ada pemisahan antara negara dengan gereja, namun, belum ada pemisahan antara negara dengan ilmu pengetahuan 


\section{ARTIKEL}

(There is separation between state and church, there is no separation between state and science). (Feyerabend, 1982: 299).

Pemisahan antara negara dengan gereja, menurut Feyerabend oleh karenanya mesti dilengkapi dengan pemisahan antara negara dengan ilmu pengetahuan. Tujuan dari pemisahan antara ilmu pengetahuan dengan negara adalah upaya percobaan untuk mengatasi barbarisme dari abad teknik-ilmiah kita dan untuk menantang kemanusiaan, walaupun bukan sebuah gagasan yang mudah untuk dapat diwujudkan. (Feyerabend, 1982: 300). Gagasan Feyerabend yang sangat orisinal, mengingatkan bahwa bersatunya negara dengan ilmu pengetahuan dan teknologi, malah lebih sering menimbulkan tragedi kemanusiaan serta beragam bentuk eksploitasi dari kelompok manusia yang satu terhadap manusia yang lain, dari negara-negara yang kuat terhadap negara-negara yang lemah. Hal tersebut bisa terjadi demi memuaskan ambisi-ambisi serta prestise sosial, politik dan ekonomi yang seringkali dijalankan dengan cara-cara yang keras serta barbar.

Feyerabend memang berada dalam setting sosial-politik abad keduapuluh, satu situasi ketika kemajuan ilmu pengetahuan dan teknologi yang demikian pesat, berbarengan dengan eksploitasi besar-besaran dari manusia yang satu terhadap yang lain dengan kekerasan yang merajalela di mana-mana. Abad keduapuluh yang diwarnai kekerasan, seperti telah ditengarai oleh Lenin sebagai abad peperangan dan revolusi. Pada abad ini, kekerasan dipercaya sebagai instrumen untuk mencapai kekuasaan. Kekerasan menjadi alat untuk mencapai kekuasaan. Timbulnya kekerasan disebabkan karena politik tidak dapat mengontrol potensi pemusnah yang ditimbulkan oleh teknologi, padahal teknologi sering digunakan dalam konflik bersenjata. (Pitaloka, 2004: 66). 


\section{ARTIKEL}

Namun, di samping meluasnya teror dalam bentuknya yang barbar serta berkecamuknya tragedi peperangan demi peperangan, abad keduapuluh juga menorehkan prestasi pencapaian teknologi yang mengagumkan. Imaji tentang ilmu pengetahuan abad keduapuluh di dalam pikiran ilmuwan dan orang-orang awam bergantung pada keajaiban-keajaiban teknologis seperti televisi berwarna, kisah pendaratan di bulan, sinar infra-merah serta berbagai penemuan lain yang tidak terhitung jumlahnya. Cerita dongeng menjelaskan mengapa masyarakat modern memperlakukan sains di dalam cara yang khusus dan mengapa memberinya hak-hak istimewa yang tidak dapat dinikmati oleh lembaga-lembaga lain. (Feyerabend, 1982: 300). Gagasan pemisahan sains dari negara dari Feyerabend, adalah sebagai sebuah usaha untuk menghindarkan sains sebagai 'instrumen' ideologi dengan segala hak istimewa yang dimilikinya, untuk menyokong totalitarianisme sebuah kekuasaan.

Ideologi, dalam hal ini, mengandung beberapa pengertian. Secara harfiah, ideologi seringkali dianggap sebagai ilmu pengetahuan tentang ide-ide, atau studi tentang asal-usul berbagai ide. Dalam kaitannya dengan hal-hal yang bersifat modern, ideologi seringkali diartikan sebagai spekulasi dogmatik yang tidak benar atu tidak realistis, atau bahkan palsu, serta menutupi kenyataan yang sebenarnya. (Pitaloka, 2004: 98). Sejarah masyarakat modern sendiri, telah dihiasi berbagai bentuk ideologi berbarengan dengan lahirnya Revolusi Ilmiah jilid pertama. Franz Magnis-Suseno memberikan sebuah gambaran bahwa sejak permulaan jaman modern, sekitar tiga ratus tahun yang lalu, manusia terancam oleh pelbagai ideologi dan gerakan sosial politik. Apa itu liberalisme, kapitalisme, egalitarianisme, sosialisme ekstrim, komunisme, fundamentalisme religius, populisme, fasisme, chauvinisme, integralisme, elitarisme atau birokratisme, senantiasa manusia terancam oleh struktur- 
struktur yang menindasnya. (Suseno, 1992: 101). Ideologi, dalam bentuknya yang tertutup, cenderung manipulatif serta penuh dengan kebohongan. Gagasan pemisahan sains dari negara, adalah untuk menghindarkan ilmu pengetahuan, sematamata dijadikan instrumen ideologis totaliter pihak-pihak yang berkuasa terutama terkait konteks pemikiran Feyerabend dalam Against Method, tertuju pada penganut garis ideologi liberalisme Amereka dan negara-negara Barat lainnya. Maka, Feyerabend kemudian mengemukakan argumentasi dia (1982: 300-2) untuk dapat memperkuat gagasannya.

Pertama, idealnya, negara modern adalah netral secara ideologis. Agama, mite, prasangka memiliki sebuah pengaruh, tetapi melalui medium yang berpengaruh secara politis. Prinsip-prinsip ideologis, mungkin masuk struktur pemerintahan, tetapi hanya melalui sebuah suara mayoritas dan sesudah melalui sebuah diskusi yang panjang dari konsekuensi-konsekuensinya yang mungkin ditimbulkannya. Di dalam sekolah kita agama yang utama dipikirkan sebagai fenomena historis. Agama dipikirkan sebagai bagian dari kebenaran seandainya para orang tua menuntut instruksi cara-cara yang lebih langsung. Hal ini akan mengarahkan mereka untuk menentukan pendidikan agama untuk anak-anak mereka. Dukungan finansial untuk ideologiideologi tidak melebihi dukungan dana untuk partai-partai dan kelompok-kelompok pribadi. Negara dan ideologi, negara dan gereja, negara dan mite, dipisahkan secara hati-hati.

Kedua, negara dan sains, bagaimanapun, bekerja bersama-sama secara tertutup. Besar sekali jumlah pengeluaran anggaran atas pengembangan gagasan-gagasan ilmiah. Hubungan-hubungan kemanusiaan tetap disepakati di dalam cara-cara yang ilmiah, sebagaimana ditunjukkan lewan program-program pendidikan, proposal 


\section{ARTIKEL}

E-ISSN: 2615-5028

untuk reformasi penjara, pelatihan-pelatihan prajurit, dan sebagainya. Keseluruhan subjek-subjek ilmiah adalah subjek-subjek yang hampir diwajibkan di sekolah kita. Ketika para orang tua dari anak berusia 6 tahun dapat memutuskan untuk menginstruksikan dasar-dasar dari keyakinan agama, atau untuk mengabaikannya secara bersama-sama, mereka tidak memiliki kebebasan yang sama di dalam perkara ilmu pengetahuan. Fisika, astronomi, sejarah harus dipelajari. Kedudukannya tidak dapat diganti dengan ilmu-ilmu magis, astrologi atau melalui studi legenda-legenda.

Seseorang tidak dapat mengatakan: sebagian orang percaya bahwa bumi bergerak mengelilingi matahari ketika yang lain menganggap bumi sebagai ruang melengkung yang berisi matahari, planet-planet, dan bintang-bintang yang menetap. Seseorang mengatakan: bumi bergerak mengelilingi matahari -apa saja pandangan yang lain, hanyalah ‘kepandiran’ belaka.

Akhirnya, ketiga, cara kita untuk menerima atau menolak ide-ide ilmiah adalah berbeda secara radikal dari prosedur-prosedur keputusan demokratis. Kita menerima hukum-hukum dan fakta-fakta ilmiah, kita mengajar mereka di dalam sekolah kita, kita mengajarkan bagi mereka keputusan-keputusan politis yang penting, tetapi tanpa pernah mensubjekkan mereka untuk sebuah suara. Ilmuwan tidak mensubjekkan mereka untuk sebuah suara -atau setidak-tidaknya ini adalah apa yang mereka katakan, dan kalangan awam secara pasti bukanlah objek mereka untuk sebuah suara. Proposal yang konkret terkadang didiskusikan dan sebuah suara dianjurkan. Tetapi secara prosedur tidak diperluas kepada teori-teori umum dan fakta-fakta ilmiah. Masyarakat modern adalah 'Copernican' tidak disebabkan Copernicanisme terletak pada sebuah kartu suara, pensubjekkan untuk sebuah debat demokratis dan kemudian disuarakan di dalam sebuah mayoritas yang sederhana; ini dikatakan 


\section{ARTIKEL}

'Copernican' sebab para ilmuwan adalah Kaum Copernican dan sebab seseorang menerima kosmologi mereka secara tidak kritis sebagaimana seseorang pernah menerima kosmologi para uskup dan kardinal.

Gagasan revolusioner pemisahan ilmu pengetahuan dari negara akan memposisikan para ilmuwan untuk bekerja secara independen, tanpa campur tangan kepentingan ideologis serta propaganda totaliter pihak-pihak pemegang otoritas publik. Lalu, kalau demikian, timbul pertanyaan: di manakah partisipasi para ilmuwan terhadap pembangunan negaranya? Pada halaman akhir Against Method, Feyerabend (1982: 309) menyampaikan pandangannya bahwa para ilmuwan tentu saja akan berpartisipasi di dalam keputusan-keputusan pemerintah agar setiap orang -termasuk para ilmuwan, berpartisipasi dalam setiap keputusan. Para ilmuwan tetap mengajarkan metode-metode yang dipergunakan atau kebenaran dari kepercayaankepercayaan dasar seperti teori evolusi, atau teori kuantum dan bukan berbuat demi otoritas metodologi. Dengan kata lain bahwa kaum ilmuwan tidak memberikan sesuatu di luar batas jangkauan keilmuannya, apalagi untuk mengembangkan otoritas pihak penguasa.

Terkait dengan istilah otoritas (authority), Hannah Arendt telah membedakan istilah terkait dengan kekuatan (strength) serta daya (force). Kekuatan merupakan sifat atau karakter yang dimiliki setiap objek atau individu yang pada hakikatnya berdiri sendiri serta dapat dilihat dari relasi antara objek atau individu terkait dengan pihak atau orang lain. Yang dimaksud dengan daya adalah sebuah terminologi yang lebih tepat digunakan untuk menggambarkan ‘kekuatan alam’ seperti munculnya pelepasan energi secara fisika. Berbeda dengan kekuatan dan daya, Arendt melihat otoritas sebagai elemen yang ada pada setiap individu. Otoritas tidak dapat dipertanyakan atau 


\section{ARTIKEL}

E-ISSN: $2615-5028$

dituntut oleh pihak yang harus mematuhinya. Otoritas tidak membutuhkan paksaan. Oleh karenanya, yang menjadi musuh terbesar dari otoritas adalah ketidakpatuhan dan pengabaian (Pitaloka, 2004: 60-61). Terkait Feyerabend, maka otoritas seperti yang dimaksudkan oleh Arendt adalah terkait dengan kedudukan para penguasa dengan pihak yang dikuasainya. Atau antara negara di satu sisi dengan masyarakat pada sisi yang lain. Maka, ketika para ilmuwan sebagai bagian dari masyarakat sepenuhnya berintegrasi dengan kepentingan-kepentingan politik, yang terjadi kemudian adalah ilmuwan menjadi 'pelayan' kekuasaan.

Walaupun terjadi pemisahan sains dengan negara, tentu saja, keseluruhan dari tradisi termasuk sains di dalamnya, tetap memiliki akses serta hak-hak yang sederajat terhadap pusat-pusat kekuasaan. Setting sosial ideal inilah yang dicita-citakan dalam sebuah masyarakat demokratis yang bebas, yang menjadi gagasan pokok dalam buku Science in Free Society (1998) sebagai kondisi ketika 'a society in which all traditions have equal right and equal access to the centers of power (Feyerabend, 1978: 9). Feyerabend membantah bahwa ilmu pengetahuan merupakan ancaman bagi demokrasi. Untuk mempertahankan masyarakat menentang sains, kita harus menempatkan sains di bawah kontrol demokratis dan didasarkan pada sikap skeptis terhadap 'ahli-ahli pertukangan' ilmiah, memberi mereka nasihat seandainya mereka dikontrol secara demokratis oleh tim penilai yang terdiri dari orang-orang awam.

Pemikiran Feyerabend ini menunjukkan adanya relasi antara kehidupan sosial dan pemikiran politik yang paradigmatik. Hal ini telah memunculkan pluralisme politik (Rahman, 2010). Begitu pula halnya dengan teori ekonomi yang telah memunculkan banyak episteme, seperti Merkantilisme, Ekonomi Campuran, Darwinisme Sosial, Komunisme, Ekonomi Laissez-Faire, dan Pasar Bebas (Rahman, 


\section{ARTIKEL}

2018). Alhasil, dengan ide demokrasi sosial itu, Feyerabend seperti akan mengambil manfaat dari adanya masyarakat yang terbuka (open society) seperti yang ditegaskan oleh Karl R. Popper (2012), bahkan lebih terbuka dari itu. Tidak heran jika istilah yang digunakan Feyerabend adalah Anarkisme Epistemologis. Dengan itu ditegaskan bahwa ilmu adalah urusan pribadi, bersifat individual, dan berarti mendorong pada kemandirian dalam pemilihan ilmu.

Akhirnya, pemikiran Feyerabend ini dapat memberikan suatu sinaran bagi kehidupan sosial, bahwa tiap orang berhak untuk mengemukakan dan ikut serta dalam perekayasaan sosial secara sama di depan hukum. Demikian karena ide-ide sosial, seperti halnya ilmu pengetahuan, akan berkembang apabila ada kebebasan dalam berekspresi. Inilah yang dimaksud dengan demokrasi sosial.

\section{Kesimpulan}

Dengan idenya tentang demokrasi sosial, Feyerabend hendak menciptakan kondisi kebebasan dari segala tirani dominasi yang telah terlembagakan sedemikian rupa di dalam bahasa komunitas ilmiah. Feyerabend yang mendapatkan pengaruh dari John Stuart Mill mencita-citakan kehidupan ilmiah demokratis yang bisa terlepas dari segala bentuk tirani pengetahuan. Maka prinsip 'apa saja boleh', selaras dengan slogan 'pengembangbiakan' (proliferation) untuk menggantikan semangat rasionalisme ilmiah seperti tergambarkan di dalam slogal falsifikasionisme, induktivisme serta risetprogramisme.

Maksud dari prinsip pengembangbiakan ini adalah membiarkan berbagai gagasan, berkembang secara lebih otonom tanpa mesti ada yang mendominasi atau menteror satu sama lain. Maka prinsip pengembangbiakan dapat menerapkan serta 


\section{ARTIKEL}

E-ISSN: $2615-5028$

menerima adanya pluralisme metodologi, pluralisme teori dan sistem pemikiran serta kerangka institusional, sehingga penindasan ilmiah pun mesti diakhiri. Maka untuk mendukung gagasan demokratisasi ilmiah serta agar sains terhindar menjadi alat penindasan, Feyerabend menganjurkan pemisahan sains dari negara, melengkapi pemisahan agama dari negara seperti yang lazim terjadi di negara-negara Barat.

Walaupun demikian, keseluruhan dari varian tradisi yang beragam termasuk sains di dalamnya, tetapi memiliki akses serta hak-hak yang sederajat terhadap pusatpusat kekuasaan. Sains mesti ditempatkan di bawah mekanisme kontrol demokratis oleh tim penilai dari kalangan orang-orang awam. Selain itu, gagasan pemisahan sains dari negara, dapat mereposisi peran ilmuwan, sebagai elemen independen dengan menjadikan sains dalam posisi yang netral, di luar campur tangan negara.

\section{DAFTAR PUSTAKA}

Falckenberg, Richard. History Of Modern Philosophy. BoD-Books on Demand, 2019.

Ferry, Luc. A brief history of thought: A philosophical guide to living. Canongate Books, 2019.

Feyerabend, P.K., Against Method, London: Verso, 1982.

Feyerabend, P.K., Sains in Free Society, London: New Left Books, 1978.

Geraudy, Roger, Janji-Janji Islam (diterjemahkan HM. Rasyidi dari Promesses de L Islam), Jakarta: PT. Bulan Bintang, 1995.

Goldmann, Lucien. The bidden God: a study of tragic vision in the Pensées of Pascal and the tragedies of Racine. Routledge, 2013. 


\section{ARTIKEL}

E-ISSN: 2615-5028

Martin, Eric C. "“The Battle is on": Lakatos, Feyerabend, and the student protests." European Journal for Philosophy of Science 9, no. 2 (2019): 28.

Pandarakalam, James Paul. "Scientific Evidences for Discarnate Existence and a Search for the Sacred." NeuroQuantology 17, no. 4 (2019).

Pitaloka, Rieke Diah, Kekerasan Negara Menular ke Masyarakat, Yogyakarta: Galang Press, 2004.

Popper, Karl. The open society and its enemies. Routledge, 2012.

Preston, John, Stanford Encyclopaedia of Philosophy, pada J.M.Preston@,reading.ac.uk, 2002.

Rahim, Rahimin Affandi Abdul, Ahmad Farid Abdul Jalal, Ahnaf Wafi Alias, and Huzaimah Ismail. "PERBANDINGAN PENDEKATAN PENJAJAHAN BRITISH DAN BELANDA." Jurnal Socio-Politica 8, no. 1 (2018): 111-126.

Rahman, M. Taufiq. "Pluralisme Politik." WAW AS AN: Jurnal Ilmiah Agama dan Sosial Budaya 34, no. 1 (2010): 1-13.

Rahman, M.T. Pengantar Filsafat Sosial. Bandung: Lekkas. 2018.

Sudarto. Metodologi Penelitian Filsafat. Jakarta: RajaGrafindo Persada, 1996.

Suseno, Franz Magnis, Berfilsafat dari Konteks, Jakarta: Gramedia Pustaka Utama, 1992. 